\title{
Synthesis of glauconite composites and study of their antibacterial activity
}

\author{
Sergey B. Venig ${ }^{1}$, Rimma K. Chernova ${ }^{1}$, Victor G. Sergeantov ${ }^{1}$, Alexey A. Selifonov ${ }^{2}$, \\ Olga G. Shapoval ${ }^{2}$, Olga V. Nechaeva ${ }^{2}$, Vladimir P. Splyukhin ${ }^{1}$, Andrey M. Zakharevich ${ }^{1}$, \\ Ekaterina I. Selifonova ${ }^{1}$, Galina N. Naumova ${ }^{1}{ }^{*}$, and Natalia N. Scherbakova ${ }^{1}$ \\ ${ }^{1}$ Saratov National Research State University, 83 Astrakhanskaya str., Saratov 410012, Russia \\ ${ }^{2}$ Saratov State Medical University, 112 Bolshaya Kazachya Street, Saratov 410012, Russia \\ *e-mail: naumova.galinka.93@mail.ru
}

\begin{abstract}
The elemental composition, the surface morphology and the sorption properties of glauconite from the Beloozerskoye deposit in Saratov Region were investigated. The nanocomposites based on glauconite as a matrix with doxycycline and tetracycline were synthesised. The antibacterial activity of the obtained composites against Staphylococcus aureus was studies. (C) 2016 Journal of Biomedical Photonics \& Engineering.
\end{abstract}

Keywords: glauconite, tetracycline, doxycycline, sorption, antibacterial composite, Staphylococcus aureus.

Paper \#3125 received 2016.11.19; revised manuscript received 2016.12.29; accepted for publication 2016.12.30; published online 2016.12.31. doi: 10.18287/JBPE16.02.040303. [Saratov Fall Meeting 2016 Special Issue].

\section{References}

1. J. M. Huggett, "Minerals/Glauconites," in Encyclopedia of Geology, 542-548 (2005).

2. V. Valanciene, R. Siauciunas, and J. Baltusnikaite, "The influence of mineralogical composition on the colour of clay body," Journal of the European Ceramic Society 30(7), 1609-1617 (2010).

3. O. A. Hegab, and A. G. Abd El-Wahed, "Origin of the glauconite from the Middle Eocene, Qarara Formation, Egypt," Journal of African Earth Sciences 123, 21-28 (2016).

4. L. M. Moretto, E. F. Orsega, and G. A. Mazzocchin, "Spectroscopic methods for the analysis of celadonite and glauconite in Roman green wall paintings," Journal of Cultural Heritage 12(4), 384-391 (2011).

5. S. S. Chang, Y. H. Shau, M. K. Wang, C. T. Ku, and P. N. Chiang, "Mineralogy and occurrence of glauconite in central Taiwan," Applied Clay Science 42(1-2), 74-80 (2008).

6. G. El-Habaak, M. Askalany, M. Faraghaly, and M. Abdel-Hakeem, "The economic potential of El-Gedida glauconite deposits, El-Bahariya Oasis, Western Desert, Egypt,” Journal of African Earth Sciences 120, 186197 (2016).

7. A. V. Voronina, V. S. Semenishchev, A. A. Bykov, M. O. Savchenko, A. S. Kutergin, and T. A Nedobuh, "Approaches to rehabilitation of radioactive contaminated territories," Journal Of Chemical Technology And Biotechnology 88(9), 1606-1611 (2013).

8. T. Bajda, and Z. Kłapyta, "Adsorption of chromate from aqueous solutions by HDTMA-modified clinoptilolite, glauconite and montmorillonite,” Applied Clay Science 86, 169-173 (2013).

9. E. H. Smith, W. Lu, T. Vengris, and R. Binkiene, "Sorption of heavy metals by Lithuanian glauconite," Water Research 30(12), 2883-2892 (1996).

10. T. J. Berger, J. A. Spadaro, S. E. Chapin, and R. O. Becker, "Electrically Generated Silver Ions: Quantitative Effects on Bacterial and Mammalian Cells," Antimicrob Agents Chemotherapy 9(2), 357-358 (1976).

11. B. Bagchi, S. Kar, S. K. Dey, S. Bhandary, D. Roy, T. K. Mukhopadhyay, S. Das, and P. Nandy, "In situ synthesis and antibacterial activity of copper nanoparticles loaded natural montmorillonite clay based on contact inhibition and ion release," Colloids Surf B Biointerfaces 108, 358-365 (2013).

12. D. Avisar, O. Primor, I. Gozlan, and H. Mamane, "Sorption of Sulfonamides and Tetracyclines to Montmorillonite Clay," Water, Air, \& Soil Pollution 209(1), 439-450 (2009).

13. J. Wang, J. Hu, and S. Zhang, "Studies on the sorption of tetracycline onto clays and marine sediment from seawater," Journal of Colloid and Interface Science 349(2), 578-582 (2010). 
14. R. Daghrir, and P. Drogui, "Tetracycline antibiotics in the environment: a review," Environ. Chem. Lett. 11(3), 209-227 (2013).

15. S. G. Walker, C. A. Flemming, F. G. Ferris, T. J. Beveridge, and G. W. Bailey, "Physicochemical interaction of Escherichia coli cell envelopes and Bacillus subtilis cell walls with two clays and ability of the composite to immobilize heavy metals from solution," Appl Environ Microbiol. 55(11), 2976-2984 (1989).

\section{Introduction}

The therapeutic capabilities of glauconite are due to the presence of the clay component of this mineral known as "green clay" and are related to many fields of medicine and cosmetology $[1,2]$. It is traditionally used for physiotherapeutic procedures in the treatment of osteochondrosis, podagra, and other arthropathies. It also facilitates fast healing of wounds and other skin lesions. Glauconite-based creams have shown good results in cosmetology, in the treatment of skin inflammations and allergy, acne, seborrhea oleosa, psoriasis, and dermatitis [3-8].

There are also data on using the glauconite-based enterosorbents in veterinary [9-10]. In the digestive tract the glauconite improves the metabolism, namely, it participates in catalytic processes, regulates the content of free intestinal fluid, the composition and concentration of electrolytes, the mineral metabolism, and the acid-base balance. The enterosorbents consisting of glauconite concentrates are used as active agents for prophylactics and treatment of gastrointestinal tract diseases in animals. In this case, glauconite can be applied both solely and in the composition of therapeutic agents and fodder. Thus, it is proposed to use glauconite in the feed additive in combination with the "Biosporin" probiotic (RU $2319391,2008)$ to in-crease the immunity and natural organism resistance in pigs.

The clay-based antibacterial preparation studied up to now mainly include metallic nanoparticles or an antibacterial medicine [11]. Thus, the montmorillonite and the bed silt are able to absorb sulphonamides and antibiotics [12, 13]. In the literature, the data on the sorption of tetracycline and doxycycline by the glauconite and on the antibacterial properties of glauconite composites with immobilised antibiotics are absent. Alongside with sulphanilamides and penicillins, the tetracycline antibiotics are most frequently used in medicine and veterinary because of their high antimicrobial activity and low cost of the preparations. To date nearly 40 natural and 3000 synthesised tetracycline antibiotics are known. Annually in veterinary more than 3350 tons of tetracyclines are used in Russia, more than 3200 tons in the USA, and more than 2575 tons in Europe [14]. Therefore the issue of synthesis and study of antibacterial composites based on natural sorbents and tetracycline antibiotics and possessing high bactericidal activity for both external and internal use is interesting and urgent.

\section{Materials and Methods}

As a matrix for the composites, we used the enriched fraction of glauconite, extracted from the glauconite sand using the magnetic separation technique and containing $85 \%$ of glauconite. The morphological characteristics of glauconite were studied using the scanning electron microscope (SEM) MIRA 2 LMU (Tescan, Czech Republic). The elemental composition of the enriched glauconite was analysed using the energy dispersive microanalysis system INCA Energy 350 (SEM), as well as the X-ray fluorimeter Innov X-5000 with silicon drift detector. The texture characteristics of the aluminosilicate were studied by means of the Brunauer-Emmett-Teller (BET) method of measuring the specific sorbent surface, based on the measurement of equilibrium adsorption of nitrogen at $77 \mathrm{~K}$ using the Quantachrome nova 2200 system.

The role of biologically active components of the nanocomposite was played by the antibacterial preparations tetracycline and doxycycline. The glauconite-antibiotic composite was obtained by means of sorption in the static regime at room temperature. To get the composite the portions of $0.5 \mathrm{~g}$ of glauconite were put in conic flasks, poured with $25 \mathrm{ml}$ of the initial aqueous solution of tetracycline (TC) or doxycycline (DC) hydrochloride $\left(\mathrm{C}_{0}(\mathrm{TC})=5.198 * 10^{-5} \mathrm{~mole} / \mathrm{l}\right.$ and $\mathrm{C}_{0}(\mathrm{DC})=8.316 \cdot 10^{-5}$ mole $\left./ \mathrm{l}\right)$ and mixed during 90 minutes by means of a magnetic mixer. After filtering, the residual solid phase was dried at room temperature. The residual concentration of antibiotics in the filtrate was determined by means of spectrophotometry $(\lambda=346$ $\mathrm{nm}$ ) using the preliminarily drawn calibration plot.

The antibacterial activity of the obtained composites of glauconite with immobilised antibiotics was assayed using the strain S. aureus ATCC 6538-P. The broth culture of the strain was volumetrically seeded by $1 \mathrm{ml}$ $\left(10^{5} \mathrm{CFU}\right)$ on meat infusion agar and the grown colonies were counted immediately and in 3 and 6 hours after the seeding. For this purpose to the portions of the composite $100 \mathrm{ml}$ of sterile beef-extract broth (BEB) was added. Then the suspension of pure one-day culture of the above strain, prepared using the opacity standard of L. A. Tarasevich State Institute of Standardization and Control of Biomedical Preparations (OT 0.75 at the wavelength $600 \mathrm{~nm}$ ) and diluted by saline to the final concentration of $10^{5} \mathrm{CFU} / \mathrm{ml}$ was inoculated by $1 \mathrm{ml}$. The seeded cultures in the BEB with glauconite portions without antibiotics and the medium without these substances were used for control samples. The weight portions of the composites were determined by the necessity to create its sub-inhibiting concentrations, basing on the acceptable values of the minimal inhibiting concentrations of these antibiotics for the 
experimental strain. All seedings were triply repeated and incubated in a thermostat at $37{ }^{\circ} \mathrm{C}$. The statistical processing of the results included the calculation of the arithmetical mean of cell number (M) in $1 \mathrm{ml}$ and the standard deviation (m); then we evaluated the significant difference of the mean values from the control samples with the probability $95 \%$.

\section{Results and discussion}

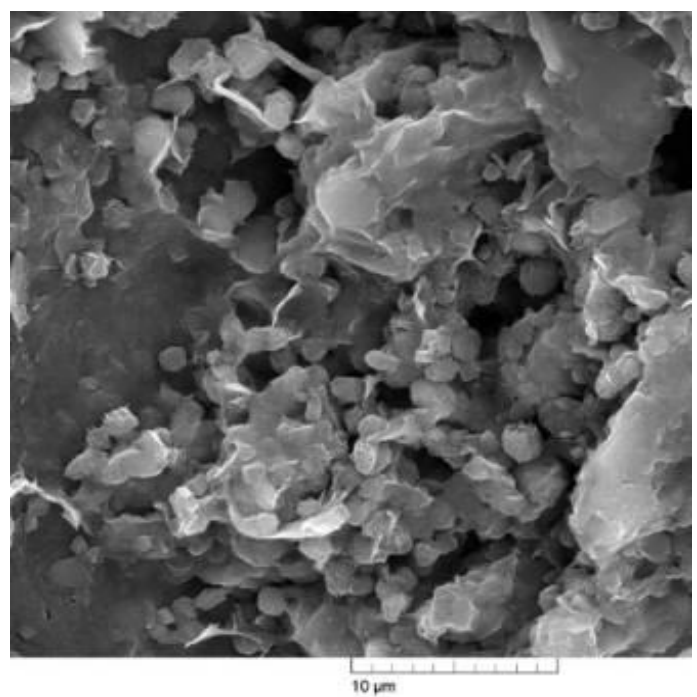

a)
We found that the grains have layered surface, formed by flakes having different shape and size. The thickness of the flakes varies from 10 to $90 \mathrm{~nm}$, and the separation be-tween them amounted to 10-200 nm (Fig. 1).

The elemental composition of the enriched glauconite determined using the energy dispersive microanalysis system INCA, as well as the X-ray fluorimeter, is presented in Table 1.

As follows from the table, the studied glauconite is characterised by a variety of macro- and microelements.

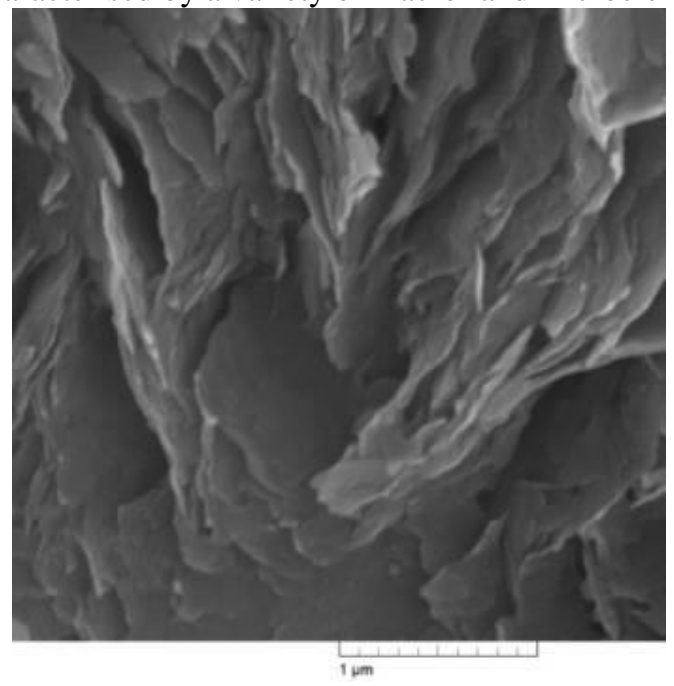

b)

Fig. 1 Electron microphotographs of the enriched glauconite. Magnification $10000 \times$ (a) and $100000 \times(b)$.

Table 1 Mean microelement (scanning electron microscope) and microelement (X-ray fluorescence analysis) composition of glauconite $(\mathrm{m}, \%)$.

\begin{tabular}{cccccccccc}
\hline Macroelement & $\mathrm{C}$ & $\mathrm{O}$ & $\mathrm{Mg}$ & $\mathrm{Al}$ & $\mathrm{Si}$ & $\mathrm{P}$ & $\mathrm{K}$ & $\mathrm{Ca}$ & $\mathrm{Fe}$ \\
\hline $\mathrm{m}, \%$ & 14.21 & 48.27 & 1.05 & 3.54 & 20.98 & 1.10 & 2.15 & 1.86 & 8.59 \\
\hline Microelement & $\mathrm{Cr}$ & $\mathrm{Mn}$ & $\mathrm{Ni}$ & $\mathrm{Co}$ & $\mathrm{Cu}$ & $\mathrm{Zn}$ & $\mathrm{V}$ & $\mathrm{Zr}$ & $\mathrm{Sr}$ \\
\hline $\mathrm{m}, \%$ & $1.3 \cdot 10^{-2}$ & $5.6 \cdot 10^{-3}$ & $3.4 \cdot 10^{-3}$ & $4.3 \cdot 10^{-3}$ & $2.1 \cdot 10^{-3}$ & $4.6 \cdot 10^{-3}$ & $1.4 \cdot 10^{-3}$ & $2.3 \cdot 10^{-3}$ & $9.8 \cdot 10^{-3}$ \\
\hline
\end{tabular}

The obtained isotherms of adsorption-desorption of nitrogen on glauconite according to the IUPAC classification belong to the isotherms of the IV type, characterised by the presence of the capillarycondensation hysteresis loop, which label the presence of mesopores having the size from 2 to $50 \mathrm{~nm}$ (Fig. 2).

The sharp increase of the isotherm at $\mathrm{P} / \mathrm{P}_{0}$ close to 1 indicates the minor presence of large pores in the sample. The sharp increase in the low-pressure region is identical to the shape of type I isotherm, typical for microporous sorbents. Note also that according to the de Boer classification the hysteresis loop shape corresponds to the type $\mathrm{B}$ and indicates the presence of slit-like pores. Thus, all studied samples possess the dominating mesoporous structure and a small number of micro- and macropores. From the adsorption and desorption branches of isotherms the following texture characteristics of the enriched glauconite were found: the specific surface $35.04 \mathrm{~m}^{2} / \mathrm{g}$, the total volume of pores $\left(\mathrm{P} / \mathrm{P}_{\mathrm{o}}=0.98\right) 0.048 \mathrm{~cm}^{3} / \mathrm{g}$.
We estimated the parameters of sorption ability of glauconite with respect to doxycycline $(\mathrm{R}=91.2 \%)$ and tetracycline $(\mathrm{R}=82.3 \%)$. They are adsorbed on the mineral surface at the expense of the chemosorption process, facilitated by the presence of hydroxyl groups in the structure of glauconite and of active groups in the structure of the studied antibiotics.

It was established that in 3 hours after the seeding, the arithmetic mean cell number $(\mathrm{M})$ of the S. aureus strain did not essentially differ from that of the control sample for the smallest composite portion with doxycycline $(0.015 \mathrm{mg})$. The antibacterial effect of the $0.03 \mathrm{mg}$ composite with doxycycline appeared to be comparable with the effect of the doxycycline preparation itself. In 6 hours of S. aureus strain incubation the significant difference of the values $(\mathrm{M})$ compared to the control samples (C) was observed for both doxycycline concentrations $(0.25$ and $0.125 \mu \mathrm{g} / \mathrm{ml})$ and the composite with the mass $0.03 \mathrm{mg}$. The $0.015 \mathrm{mg}$ portion of nanocomposite in 6 hours after the seeding did not suppress the development of bacterial colonies 
S. aureus, and the result is comparable with the control sample. The best effect of the composite was observed for the portion of $25 \mathrm{mg}$ with respect to S. aureus, the number of colonies being essentially smaller than in the control sample (Table 2).

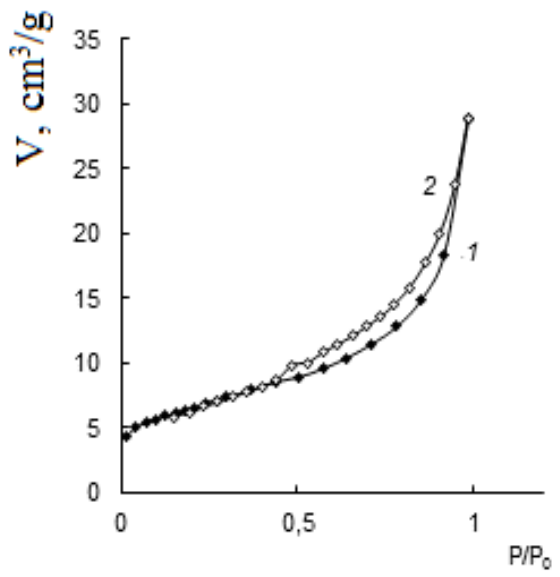

Thus the sorbed doxycycline и tetracycline in the inhibiting concentrations suppress the development of the S. aureus strain population in the logarithmic phase of the growth (Fig. 3).

Discussing the possible mechanism of the antibacterial effect of the synthesised composite, it is worth noting that besides the antibacterial properties of the antibiotics themselves, an important feature is the possibility of direct contact of the bacterial membrane with hydrophobic particles of glauconite, when the latter "encapsulates" the bacterial cells. Ref. [15] can be considered as confirming this useful property of the glauconite matrix. Walker et al. studied the interaction of bacterial membranes with the clay particles of kaolinite and smectite. They demonstrated the alignment of particles around the bacterial cell wall as a result of forming the polynuclear complex bridge $\left[\mathrm{Al}_{13}(\mathrm{OH})_{31}\right]^{7+}$.

Fig. 2 Isotherms of adsorption (1) - desorption (2) of nitrogen at $77 \mathrm{~K}$ on the enriched glauconite.

Table 2 The mean number of S. aureus cells in $1 \mathrm{ml}$ of BEB (M, CFU/ml) and its standard deviation (m) depending on the cultivation conditions $(n=3, p=0.95)$.

\begin{tabular}{|c|c|c|c|c|c|c|c|}
\hline \multicolumn{8}{|c|}{$\mathrm{M} \pm \mathrm{m}$ CFU/ml } \\
\hline \multicolumn{8}{|c|}{ Doxycycline } \\
\hline Seeding time & $\mathrm{K}^{1}$ & $\begin{array}{l}\text { Glauconite } \\
0.5 \mathrm{mg}\end{array}$ & $\begin{array}{l}\text { Glauconite } \\
0.25 \mathrm{mg}\end{array}$ & $\begin{array}{c}\text { Doxycycline } \\
0.25 \mu \mathrm{g} / \mathrm{ml}\end{array}$ & $\begin{array}{l}\text { Doxycycline } \\
0.125 \mu \mathrm{g} / \mathrm{ml}\end{array}$ & $\begin{array}{c}\text { Composite } \\
0.03 \mathrm{mg}\end{array}$ & $\begin{array}{c}\text { Composite } \\
0.015 \mathrm{mg}\end{array}$ \\
\hline $0 \mathrm{~h}$ & $600 \pm 290$ & $420 \pm 50$ & $550 \pm 80$ & $330 \pm 70$ & $330 \pm 90$ & $350 \pm 160$ & $290 \pm 130$ \\
\hline $\begin{array}{c}3 \mathrm{~h} \\
\text { (Lag-phase) }\end{array}$ & $1040 \pm 260$ & $570 \pm 180$ & $970 \pm 110$ & $440 \pm 170^{2}$ & $410 \pm 110^{2}$ & $490 \pm 170^{2}$ & $1120 \pm 450$ \\
\hline $\begin{array}{c}6 \mathrm{~h} \\
\text { (Log-phase) }\end{array}$ & $7230 \pm 2350$ & $8730 \pm 960$ & $6490 \pm 2700$ & $620 \pm 20^{2}$ & $500 \pm 90^{2}$ & $660 \pm 210^{2}$ & $12010 \pm 5210$ \\
\hline \multicolumn{8}{|c|}{ Tetracycline } \\
\hline Seeding time & $\mathrm{K}^{1}$ & $\begin{array}{l}\text { Glauconite } \\
2.5 \mathrm{mg}\end{array}$ & $\begin{array}{l}\text { Glauconite } \\
1.25 \mathrm{mg}\end{array}$ & $\begin{array}{c}\text { Tetracycline } 4 \\
\mu \mathrm{g} / \mathrm{ml}\end{array}$ & $\begin{array}{l}\text { Tetracycline } \\
2 \mu \mathrm{g} / \mathrm{ml}\end{array}$ & $\begin{array}{l}\text { Composite } \\
2.5 \mathrm{mg}\end{array}$ & $\begin{array}{l}\text { Composite } \\
1.25 \mathrm{mg}\end{array}$ \\
\hline $0 \mathrm{~h}$ & $323 \pm 93$ & $451 \pm 80$ & $442 \pm 65$ & $451 \pm 77$ & $470 \pm 62$ & $519 \pm 29$ & $446 \pm 84$ \\
\hline $\begin{array}{c}3 \mathrm{~h} \\
\text { (Lag-phase) } \\
\end{array}$ & $1967 \pm 208$ & $1663 \pm 323$ & $1693 \pm 170$ & $630 \pm 262^{2}$ & $710 \pm 252^{2}$ & $777 \pm 212^{2}$ & $753 \pm 152^{2}$ \\
\hline $\begin{array}{c}6 \mathrm{~h} \\
\text { (Log-phase) }\end{array}$ & $12767 \pm 568$ & $13500 \pm 888$ & $13800 \pm 1277$ & $673 \pm 392^{2}$ & $798 \pm 282^{2}$ & $937 \pm 182^{2}$ & $1267 \pm 252^{2}$ \\
\hline
\end{tabular}

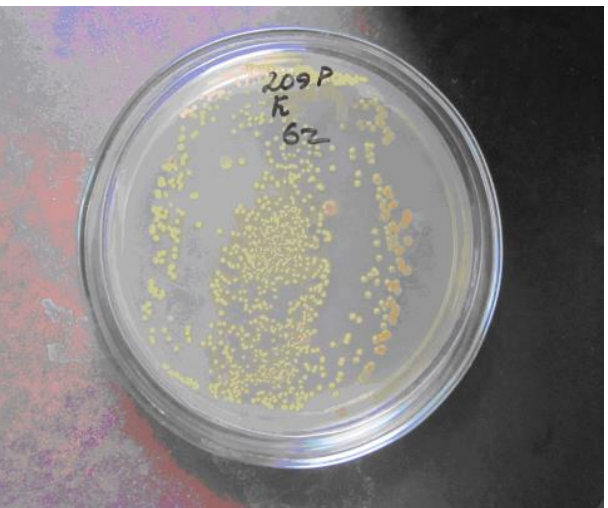

a)

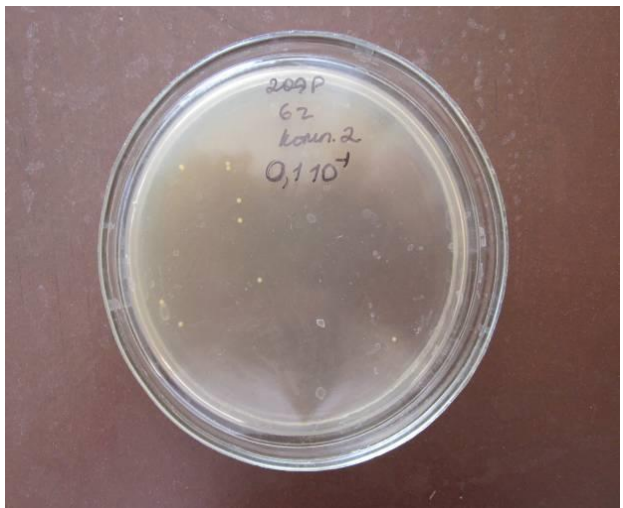

b)

Fig. 3 Character of changes in the $S$. aureus ATCC 6538-P colonies after 6 hours of cultivation: a) control measured seeding $(7230 \pm 2350 \mathrm{CFU} / \mathrm{ml}) \mathrm{b})$ measured seeding $(660 \pm 210 \mathrm{CFU} / \mathrm{ml})$ after treating with the glauconite composite with immobilised doxycycline. 


\section{Conclusion}

We established the macro- and microelement composition of the glauconite, the squamous surface of its grains, some texture characteristics and good adsorption capacity for the antibiotics tetracycline and doxycycline.

The tetracycline and doxycycline antibacterial preparations were immobilised in the glauconite matrix. The obtained composites in the inhibiting concentrations suppress the growth of the staphylococci. Significant difference in the number of $S$. aureus colonies compared to the control seedings are demonstrated. Thus, it is interesting to perform further studies of bactericidal properties of glauconite composites with other strains of microorganisms and to evaluate the prospects of their applications in medicine and veterinary. 